\title{
Continuous synthesis of bromoalkyl glycosides by Fischer glycosylation in a microreactor
}

\author{
Jessica Jung ${ }^{1} \cdot$ Lars Kaiser $^{1,2} \cdot$ Hans-Peter Deigner ${ }^{1,3,4} \cdot$ Magnus S. Schmidt $^{1}$ (i)
}

Received: 23 July 2021 / Accepted: 26 August 2021 / Published online: 20 September 2021

(c) The Author(s) 2021

\begin{abstract}
In this study, bromoalkyl glycosides were successfully synthesized in microreactor scale by Fischer glycosylation. Yields between 24 and $40 \%$ after purification were achieved using various acidic catalysts and conditions. In some experiments, yields $180 \%$ higher than with previously known methods could be achieved. This study showed also that reversed-phase flash chromatography is more successful than normal-phase flash chromatography for the purification of bromoalkyl glycosides. Furthermore, longer bromoalcohols were shown to be more compatible than shorter bromoalcohols under these reaction conditions.
\end{abstract}

Keywords Microreactor $\cdot$ Carbohydrates $\cdot$ Fischer glycosylation $\cdot$ Glycosides $\cdot$ Bromides $\cdot$ Linker

\section{Introduction}

Carbohydrates play a major role in a multitude of biological processes and procedures, for example in signaling, cell-cell communication, and molecular and cellular targeting $[1,2]$. Thus, there is great interest in the synthesis of glycomimetics for biochemical and medical purposes [3, 4]. It is important to equip these glycomimetic molecules with a functionalized spacer to allow binding to transport molecules or to solid surfaces. Bromoalkyl glycosides are important components in a variety of syntheses of glycomimetics,

\section{Article highlights}

- In the experiments in which 10-bromo-1-decanol was used as the bromoalcohol, yields were achieved exceeding more than $180 \%$ compared to other methods.

- Various acidic catalysts and reaction conditions have been monitored.

- For the purification of the glycosides, reversed phase chromatography was used instead of normal phase chromatography, as in normal phase chromatography additional side reactions occured.

Magnus S. Schmidt

Magnus.Schmidt@hs-furtwangen.de

Jessica Jung

jessica.jung@hs-furtwangen.de

Lars Kaiser

kal@hs-furtwangen.de

Hans-Peter Deigner

Hans-Peter.Deigner@hs-furtwangen.de such as the synthesis of glycosylated nordihydroguaiaretic acids as anti-cancer compounds [5]. Bromoalkyl glycosides are very promising for use as functionalized spacers [6]. In order to apply bromoalkyl glycosides on an industrial scale, production on a technical scale is necessary. For synthesis of more complex or functionalized glycosides various modern glycosylation methods, either chemical or biochemical, are available such as the trichloroacetimidate method[7-9] or usage of enzymes[10]. Nonetheless modern glycosylation methods are related to more or less complex protecting strategies resulting in multistep reactions. Therefore, until date, the Fischer glycosylation is still an interesting method for the synthesis of glycosides [11]. Indeed, various variants have been implemented in the past decades including the use of microwave irradiation[12], various catalysts[13-15] and ionic liquids[16, 17]. For these, however, challenges such as the thermodynamic handling of the chemical synthesis

1 Institute of Precision Medicine, Medical and Life Sciences Faculty, Furtwangen University, Jakob-Kienzle-Str. 17, 78054 VS-Schwenningen, Germany

2 Institute of Pharmaceutical Sciences, University of Freiburg, Albertstraße 25, 79104 Freiburg i. Br, Germany

3 EXIM Department, Fraunhofer Institute IZI Leipzig, Schillingallee 68, 18057 Rostock, Germany

4 Faculty of Science, Associated Member of Tuebingen University, Auf der Morgenstelle 8, 72076 Tübingen, Germany 
of glycosides by Fischer glycosylation must be overcome. A promising approach for this is the production of bromoalkyl glycosides in a continuously operated microreactor [18]. Microreactors are already used today for various organic syntheses [19]. Microreaction technology is characterised by an excellent mass and heat transfer and thus enables higher yields and selectivity in syntheses compared to conventional batch processes. It thus offers the possibility to design these syntheses efficiently and to optimise their reaction conditions [20]. Furthermore, microreaction technology enables processes with greatly improved sustainability and efficiency in terms of energy and material consumption. The high selectivity, associated with the synthesis of biomolecules in the microreactor, enables the rapid development of important products for biomedical applications and their production processes. As a result, the development and production of medical products from laboratory to production scale becomes more cost- and time-efficient [19].

Fischer glycosylation is an acid-catalysed name reaction in which reducing saccharides react with an alcohol to form a glycoside as shown in Fig. 1. The reaction mechanism of Fischer glycosylation results in a mixture of stereoisomers. This mixture consists of pyranosides and furanosides, which are in chemical equilibrium via open-chain intermediates. The $\alpha$ - and $\beta$-pyranosides are thermodynamically more stable than the furanosides, with the $\alpha$-pyranoside being the thermodynamically more stable anomer [21].

Microreaction technology is a technology for a scaleddown design of process plants, for example reactors [22]. Fischer glycosylations have already been successfully carried out in microreactors. It has been shown that similar yields are achievable as for example using microwave radiation, which is the current state of the art [23]. However, microwave-mediated processes suffer from their poor scalability and, in some cases with Fischer glycosylations, also from an explosion risk due to the existing headspace caused by the used and potentially flammable alcohols. Appropriate thermodynamic handling of microreactors provides a safe and time-saving method for this form of energy-intensive chemistry. There is also no risk of explosion when using a microreactor, as the microreactor has a negligible headspace. Further, the development of a continuous process of Fischer glycosylation in the microreactor provides a promising basis for numberingup the process. [23]

Fig. 1 Visualisation of the Fischer glycosylation with D-glucose (1) and longer bromoalcohols

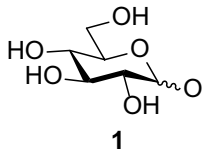

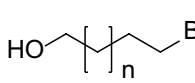

2: $\mathrm{n}=3$

3: $n=5$

4: $n=7$

\section{Results and discussion}

Table 1 shows the experiences of the study. The yields mentioned in the tables refer to yields achieved after purification.

In experiments with 2-bromo-ethanol, qualitative detection of the product was possible in test number 3. In experiment number 6 , methoxyethanol could be detected after purification. This is an indication that the 2-bromoethanol in the NP column reacts with the methanol-containing solvent. It was possible to detect the product in test number 3 because a preparative TLC (thin layer chromatography) was used instead of the column for purification which reduced the contact time of the product with the solvent and the column. In experiment number 2 , reversed phase $(\mathrm{RP}-\mathrm{C} 18)$ silica gel was used instead of normal phased (NP) silica gel, but no product was detected either. This may be due to the fact that under these experimental conditions no product or only little amounts could be obtained and therefore, the quantity was below the detection limit. In experiment number 3 , in which product could be qualitatively detected, the temperature in the reactor was significantly higher, at $120^{\circ} \mathrm{C}$ instead of $90{ }^{\circ} \mathrm{C}$. This is an indication that higher temperatures are more likely to afford the desired product.

No product was detectable in the experiments with 3-bromo-1-propanol. It is assumed that 2-bromoethanol and 3-bromo-1-propanol as bromoalcohols are probably too reactive due to the higher electrophilicity of the carbon bearing the bromine. Therefore, compared to the longer bromoalcohols, for example 6-bromo-hexan-1-ol, very little product is produced under these reaction conditions, or the product already reacts with other substances in the reactor or in the NP chromatography. Though no side products have been isolated or identified the TLC analysis of the reaction mixture supports our assumption.

In the experiments with n-octanol, no product was detectable after purification by NP-silica gel, or a liquid-liquid extraction. Only when purified by RP-silica gel, product could be isolated. The protonic acids $\mathrm{H}_{2} \mathrm{SO}_{4}$, trifluoroacetic acid and the Lewis acid Trimethylsilyl trifluoromethanesulphonate (TMSOTf) were tested as catalysts in the experiments with n-octanol. RP silica gel was only used in the purification of the experiments with Lewis acid. In the thin layer chromatographies of the reactor outflow of the experiments with $\mathrm{H}_{2} \mathrm{SO}_{4}$ and trifluoroacetic acid, spots with the same RF value were detected as when using TMSOTf. 
Table 1 Results of the feasibility study of a continuous synthesis of bromoalkyl glycosides in the microreactor by Fischer glycosylation

\begin{tabular}{|c|c|c|c|c|}
\hline $\mathrm{Nr}$ & Materials & $\begin{array}{l}\text { Process conditions in } \\
\text { the microreactor }\end{array}$ & Purification method & Yield / \% \\
\hline 1 & $\begin{array}{l}\text { 2-Bromoethanol } \\
\text { (50 mmol) } \\
\mathbf{1}(8.33 \mathrm{mmol}) \\
\mathrm{H}_{2} \mathrm{SO}_{4}(100 \mu \mathrm{L})\end{array}$ & $\begin{array}{l}\text { Retention time: } 10 \mathrm{~min} \\
\text { Temperature: } 75^{\circ} \mathrm{C}\end{array}$ & $\begin{array}{l}\text { NP-Flash-Chromatography, } 60 \text { g Silica gel, } \\
\text { Eluent: DCM } 83.33 \%(\mathrm{v} / \mathrm{v}) \text { and Methanol } \\
16.67 \%(\mathrm{v} / \mathrm{v})\end{array}$ & - \\
\hline 2 & $\begin{array}{l}\text { 2-Bromoethanol } \\
(36.67 \mathrm{mmol}) \\
\mathbf{1}(6.10 \mathrm{mmol}) \\
\mathrm{H}_{2} \mathrm{SO}_{4}(100 \mu \mathrm{L})\end{array}$ & $\begin{array}{l}\text { Retention time: } 10 \mathrm{~min} \\
\text { Temperature: } 90^{\circ} \mathrm{C}\end{array}$ & $\begin{array}{l}\text { RP-Flash-Chromatography, } 60 \mathrm{~g} \text { C18-Silica gel, } \\
\text { Eluent: } \mathrm{H}_{2} \mathrm{O} 5 \%(\mathrm{v} / \mathrm{v}) \text { and Ethanol 95\% (v/v) }\end{array}$ & - \\
\hline 3 & $\begin{array}{l}\text { 2-Bromoethanol } \\
\text { (50 mmol) } \\
\mathbf{1}(8.33 \mathrm{mmol}) \\
\mathrm{H}_{2} \mathrm{SO}_{4}(100 \mu \mathrm{L})\end{array}$ & $\begin{array}{l}\text { Retention time: } 10 \mathrm{~min} \\
\text { Temperature: } 120^{\circ} \mathrm{C}\end{array}$ & $\begin{array}{l}\text { Preperative DC instead of flash-chromatography } \\
\text { Eluent: DCM } 83.33 \%(\mathrm{v} / \mathrm{v}) \text { and Methanol } \\
16.67 \%(\mathrm{v} / \mathrm{v})\end{array}$ & Qualitative evidence \\
\hline 4 & $\begin{array}{l}\text { 2-Bromoethanol } \\
(36.67 \mathrm{mmol}) \\
\mathbf{1}(6.10 \mathrm{mmol}) \\
\mathrm{H}_{2} \mathrm{SO}_{4}(100 \mu \mathrm{L})\end{array}$ & $\begin{array}{l}\text { Retention time: } 10 \mathrm{~min} \\
\text { Temperature: } 120^{\circ} \mathrm{C}\end{array}$ & $\begin{array}{l}\text { NP-Flash-Chromatography, } 60 \mathrm{~g} \text { Silica gel, } \\
\text { Eluent: DCM } 90 \%(\mathrm{v} / \mathrm{v}) \text { and Methanol 10\% (v/v) }\end{array}$ & - \\
\hline 5 & $\begin{array}{l}\text { 2-Bromoethanol } \\
\text { (50 mmol) } \\
\mathbf{1}(8.33 \mathrm{mmol}) \\
\mathrm{H}_{2} \mathrm{SO}_{4}(100 \mu \mathrm{L})\end{array}$ & $\begin{array}{l}\text { Retention time: } 15 \mathrm{~min} \\
\text { Temperature: } 120^{\circ} \mathrm{C}\end{array}$ & $\begin{array}{l}\text { NP-Flash-Chromatography, } 60 \mathrm{~g} \text { Silica gel, } \\
\text { Eluent: DCM } 90 \%(\mathrm{v} / \mathrm{v}) \text { and Methanol 10\% (v/v) }\end{array}$ & - \\
\hline 6 & $\begin{array}{l}\text { 2-Bromoethanol } \\
(16.67 \mathrm{mmol}) \\
\mathbf{1}(2.78 \mathrm{mmol}) \\
\mathrm{H}_{2} \mathrm{SO}_{4}(100 \mu \mathrm{L})\end{array}$ & $\begin{array}{l}\text { Retention time: } 5 \mathrm{~min} \\
\text { Temperature: } 120^{\circ} \mathrm{C}\end{array}$ & $\begin{array}{l}\text { NP-Flash-Chromatography, } 60 \mathrm{~g} \text { Silica gel, } \\
\text { Eluent: DCM } 90 \%(\mathrm{v} / \mathrm{v}) \text { and Methanol 10\% (v/v) }\end{array}$ & $\begin{array}{l}\text { Methoxy-ethanol as } \\
\text { product identified }\end{array}$ \\
\hline 7 & $\begin{array}{l}\text { 3-Bromo-1-propanol (45 mmol) } \\
\mathbf{1}(7.5 \mathrm{mmol}) \\
\mathrm{H}_{2} \mathrm{SO}_{4}(100 \mu \mathrm{L})\end{array}$ & $\begin{array}{l}\text { Retention time: } 10 \mathrm{~min} \\
\text { Temperature: } 75^{\circ} \mathrm{C}\end{array}$ & $\begin{array}{l}\text { NP-Flash-Chromatography, } 60 \mathrm{~g} \text { Silica gel, Eluent: DCM } \\
90 \%(\mathrm{v} / \mathrm{v}) \text { and Methanol } 10 \%(\mathrm{v} / \mathrm{v})\end{array}$ & - \\
\hline 8 & $\begin{array}{l}\text { 3-Bromo-1-propanol }(15 \mathrm{mmol}) \\
\mathbf{1}(2.5 \mathrm{mmol}) \\
\mathrm{H}_{2} \mathrm{SO}_{4}(100 \mu \mathrm{L})\end{array}$ & $\begin{array}{l}\text { Retention time: } 10 \mathrm{~min} \\
\text { Temperature: } 90^{\circ} \mathrm{C}\end{array}$ & $\begin{array}{l}\text { NP-Flash-Chromatography, } 60 \mathrm{~g} \text { Silica gel, Eluent: DCM } \\
95 \%(\mathrm{v} / \mathrm{v}) \text { and Methanol } 5 \%(\mathrm{v} / \mathrm{v})\end{array}$ & - \\
\hline 9 & $\begin{array}{l}\text { n-Octanol }(7.5 \mathrm{mmol}) \\
\mathbf{1}(1.25 \mathrm{mmol}) \\
\mathrm{H}_{2} \mathrm{SO}_{4}(100 \mu \mathrm{L})\end{array}$ & $\begin{array}{l}\text { Retention time: } 5 \mathrm{~min} \\
\text { Temperature: } 120^{\circ} \mathrm{C}\end{array}$ & $\begin{array}{l}\text { NP-Flash-Chromatography, } 60 \mathrm{~g} \text { Silica gel, Eluent: DCM } \\
91 \%(\mathrm{v} / \mathrm{v}) \text { and Methanol } 9 \%(\mathrm{v} / \mathrm{v})\end{array}$ & - \\
\hline 10 & $\begin{array}{l}\mathrm{n}-\text { Octanol }(7.5 \mathrm{mmol}) \\
\mathbf{1}(1.25 \mathrm{mmol}) \\
\text { Trifluoroacetic acid } \\
(100 \mu \mathrm{L})\end{array}$ & $\begin{array}{l}\text { Retention time: } 5 \mathrm{~min} \\
\text { Temperature: } 120^{\circ} \mathrm{C}\end{array}$ & $\begin{array}{l}\text { NP-Flash-Chromatography, } 60 \mathrm{~g} \text { Silica gel, Eluent: Ethyl } \\
\text { acetate } 90 \%(\mathrm{v} / \mathrm{v}) \text { and Methanol } \\
10 \%(\mathrm{v} / \mathrm{v})\end{array}$ & - \\
\hline 11 & $\begin{array}{l}\mathrm{n} \text {-Octanol }(7.5 \mathrm{mmol}) \\
\mathbf{1}(1.25 \mathrm{mmol}) \\
\text { Trifluoroacetic acid } \\
(300 \mu \mathrm{L})\end{array}$ & $\begin{array}{l}\text { Retention time: } 5 \mathrm{~min} \\
\text { Temperature: } 120^{\circ} \mathrm{C}\end{array}$ & $\begin{array}{l}\text { Liquid-liquid extraction with sodium chloride solution } \\
\text { and THF instead of flash chromatography }\end{array}$ & - \\
\hline 12 & $\begin{array}{l}\text { n-Octanol }(7.5 \mathrm{mmol}) \\
\mathbf{1}(1.25 \mathrm{mmol}) \\
\text { TMSOTf }(225 \mu \mathrm{L})\end{array}$ & $\begin{array}{l}\text { Retention time: } 5 \mathrm{~min} \\
\text { Temperature: } 120^{\circ} \mathrm{C}\end{array}$ & $\begin{array}{l}\text { RP-Flash-Chromatography, } 60 \text { g Silica gel, Eluent: } \mathrm{H}_{2} \mathrm{O} \\
60 \%(\mathrm{v} / \mathrm{v}) \text { and Ethanol } 40 \%(\mathrm{v} / \mathrm{v})\end{array}$ & 12 \\
\hline 13 & $\begin{array}{l}\text { n-Octanol }(22.5 \mathrm{mmol}) \\
\mathbf{1}(3.75 \mathrm{mmol}) \\
\text { TMSOTf }(675 \mu \mathrm{L})\end{array}$ & $\begin{array}{l}\text { Retention time: } 5 \mathrm{~min} \\
\text { Temperature: } 120^{\circ} \mathrm{C}\end{array}$ & $\begin{array}{l}\text { RP-Flash-Chromatography, } 60 \mathrm{~g} \text { Silica gel, Eluent: } \mathrm{H}_{2} \mathrm{O} \\
60 \%(\mathrm{v} / \mathrm{v}) \text { and Ethanol } 40 \%(\mathrm{v} / \mathrm{v})\end{array}$ & 39 \\
\hline 14 & $\begin{array}{l}\mathbf{3} \text { (BrOct) }(15 \mathrm{mmol}) \\
\mathbf{1}(2.5 \mathrm{mmol}) \\
\text { TMSOTf }(225 \mu \mathrm{L})\end{array}$ & $\begin{array}{l}\text { Retention time: } 5 \mathrm{~min} \\
\text { Temperature: } 120^{\circ} \mathrm{C}\end{array}$ & $\begin{array}{l}\text { RP-Flash-Chromatography, } 60 \text { g Silica gel, Eluent: } \mathrm{H}_{2} \mathrm{O} \\
60 \%(\mathrm{v} / \mathrm{v}) \text { and Ethanol } 40 \%(\mathrm{v} / \mathrm{v})\end{array}$ & 24 \\
\hline 15 & $\begin{array}{l}\mathbf{3}(\mathrm{BrOct})(7.5 \mathrm{mmol}) \\
\mathbf{1}(1.25 \mathrm{mmol}) \\
\text { TMSOTf }(225 \mu \mathrm{L})\end{array}$ & $\begin{array}{l}\text { Retention time: } 5 \mathrm{~min} \\
\text { Temperature: } 120^{\circ} \mathrm{C}\end{array}$ & $\begin{array}{l}\text { RP-Flash-Chromatography, } 60 \mathrm{~g} \text { Silica gel, Eluent: } \mathrm{H}_{2} \mathrm{O} \\
70 \%(\mathrm{v} / \mathrm{v}) \text { and Ethanol } 30 \%(\mathrm{v} / \mathrm{v})\end{array}$ & 40 \\
\hline 16 & $\begin{array}{l}\mathbf{2}(\mathrm{BrHex})(7.5 \mathrm{mmol}) \\
\mathbf{1}(1.25 \mathrm{mmol}) \\
\text { TMSOTf }(225 \mu \mathrm{L})\end{array}$ & $\begin{array}{l}\text { Retention time: } 5 \mathrm{~min} \\
\text { Temperature: } 120^{\circ} \mathrm{C}\end{array}$ & $\begin{array}{l}\text { RP-Flash-Chromatography, } 60 \text { g Silica gel, Eluent: } \mathrm{H}_{2} \mathrm{O} \\
70 \%(\mathrm{v} / \mathrm{v}) \text { and Ethanol } 30 \%(\mathrm{v} / \mathrm{v})\end{array}$ & 34 \\
\hline
\end{tabular}


Table 1 (continued)

\begin{tabular}{|c|c|c|c|c|}
\hline $\mathrm{Nr}$ & Materials & $\begin{array}{l}\text { Process conditions in } \\
\text { the microreactor }\end{array}$ & Purification method & Yield / \% \\
\hline 17 & $\begin{array}{l}\mathbf{2}(\mathrm{BrHex})(7.5 \mathrm{mmol}) \\
\mathbf{1}(1.25 \mathrm{mmol}) \\
\text { TMSOTf }(225 \mu \mathrm{L})\end{array}$ & $\begin{array}{l}\text { Retention time: } 5 \mathrm{~min} \\
\text { Temperature: } 120^{\circ} \mathrm{C}\end{array}$ & $\begin{array}{l}\text { RP-Flash-Chromatography, } 60 \mathrm{~g} \text { Silica gel, Eluent: } \mathrm{H}_{2} \mathrm{O} \\
60 \%(\mathrm{v} / \mathrm{v}) \text { and Ethanol } 40 \%(\mathrm{v} / \mathrm{v})\end{array}$ & 26 \\
\hline 18 & $\begin{array}{l}\mathbf{4}(\mathrm{BrDec})(7.5 \mathrm{mmol}) \\
\mathbf{1}(1.25 \mathrm{mmol}) \\
\text { TMSOTf }(225 \mu \mathrm{L})\end{array}$ & $\begin{array}{l}\text { Retention time: } 5 \mathrm{~min} \\
\text { Temperature: } 120^{\circ} \mathrm{C}\end{array}$ & $\begin{array}{l}\text { RP-Flash-Chromatography, } 60 \text { g Silica gel, Eluent: } \mathrm{H}_{2} \mathrm{O} \\
60 \%(\mathrm{v} / \mathrm{v}) \text { and Ethanol } 40 \%(\mathrm{v} / \mathrm{v})\end{array}$ & 33 \\
\hline 19 & $\begin{array}{l}\mathbf{4}(\mathrm{BrDec})(7.5 \mathrm{mmol}) \\
\mathbf{1}(1.25 \mathrm{mmol}) \\
\text { TMSOTf }(225 \mu \mathrm{L})\end{array}$ & $\begin{array}{l}\text { Retention time: } 5 \mathrm{~min} \\
\text { Temperature: } 120^{\circ} \mathrm{C}\end{array}$ & $\begin{array}{l}\text { RP-Flash-Chromatography, } 60 \mathrm{~g} \text { Silica gel, Eluent: } \mathrm{H}_{2} \mathrm{O} \\
60 \%(\mathrm{v} / \mathrm{v}) \text { and Ethanol } 40 \%(\mathrm{v} / \mathrm{v}) \text {, after the elution of } \\
\text { the dibromide } \mathrm{H}_{2} \mathrm{O} 50 \%(\mathrm{v} / \mathrm{v}) \text { and Ethanol } 50 \%(\mathrm{v} / \mathrm{v})\end{array}$ & 33 \\
\hline
\end{tabular}

However, the spots were slightly less intense than in the experiments with TMSOTf as catalyst (using comparable amounts of reaction solution). Therefore, it is assumed that the use of $\mathrm{H}_{2} \mathrm{SO}_{4}$ and trifluoroacetic acid also produced product, but with lower yields compared to TMSOTf.

Furthermore, in the experiments with the longer bromoalcohols 6-bromo-1-hexanol, 8-bromo-1-octanol and 10-bromo-1-decanol, the corresponding dibromides could be isolated. It is assumed, that these represent impurities in the bromoalcohols. In support of that, a corresponding spot in TLC indicatied a second compound in the commercially available bromoalcohols.

The yield calculations in this project did not take into account the losses of reaction solution that occurred when the syringes were reconnected to the syringe pump. Product is also lost during the overall process for obtaining the bromoalkyl glycosides, for example when the fractions are combined during quenching. Here, a certain amount of solution remains in each flask in which the effluent from the microreactor has been fractionated. These losses are quite small, however, still have an significant impact at such small volumes. In the experiments in which bromoalkylglycosides were synthesised, the volume of the reaction solution was $3 \mathrm{~mL}$ to $4.5 \mathrm{~mL}$. In this case, losses of a few $100 \mu \mathrm{L}$ have an impact on the yield of the overall process. Therefore, it can be expected that even higher yields in the overall process can be achieved when using more reaction solution, as the losses in the overall process do not change. This would also be a possible explanation for the fact that the yields in the experiments with 6-bromo-1-hexanol were lower than in Williams et al. [18]. Also, one important difference between experiments 12 and 13 was that experiment number 13 used three times the reactants and catalyst than experiment number 12 . In experiment number 13 , the yield more than tripled compared to experiment number 12 .

Furthermore, it is not certain what influence the solvent dependent dilution of the reaction solution has on the yield. Williams et al. [18] did not use a solvent in their experiments. Omitting the solvent could possibly further increase the yield of product.

\section{Conclusions}

Here we demonstrate the successful synthesis of different bromoalkyl glycosides using a microreactor.

Yields of between 24 and $40 \%$ could be achieved in this project. Williams et al. [18] reported a yield of $39 \%$ in experiments with 6-bromo-1-hexanol, a yield of $27 \%$ in experiments with 8-bromo-1-octanol, as well as a yield of $18 \%$ in experiments using 10-bromo-1-decanol. Thus, in this project, the yields could be increased by approximately $150 \%$ in the experiments with 8-bromo1 -octanol and by more than $180 \%$ in experiments with 10-bromo-1-decanol. An interesting approach towards an industrial scale could be the numbering up which means parallel usage of higher amounts of such easy to use and cost-saving microreactors, nonetheless the challenge of isolation and work-up still needs to be addressed intensively.

\section{Experimental}

Figure 2 schematically shows the overall process of producing the bromoalkyl glycosides. The microreactor was conditioned with DMSO, which was also used for the production of the reaction solution and rinsed after the reaction. The reactor was then dried with air. Stopping the reaction was done by neutralising the acid, which was used as a catalyst, with $150 \mu \mathrm{L}$ triethylamine. The solution was then purified by column chromatography. The fractions from the column chromatography that contained product were then combined. Organic solvents were removed by using a rotary evaporator. The resulting solution in water finally was lyophylised resulting in purest possible product. The process control as well as the column chromatographic work up was monitored analytically with RP-TLC(RP-Silica Gel 60 F254, M\&N, layer thickness $0.2 \mathrm{~mm}$ ) with detection by Cerium(IV) ammonium nitrate.

The amount of DMSO as solvent in the reaction solutions was variable and depended on the solubility of the 


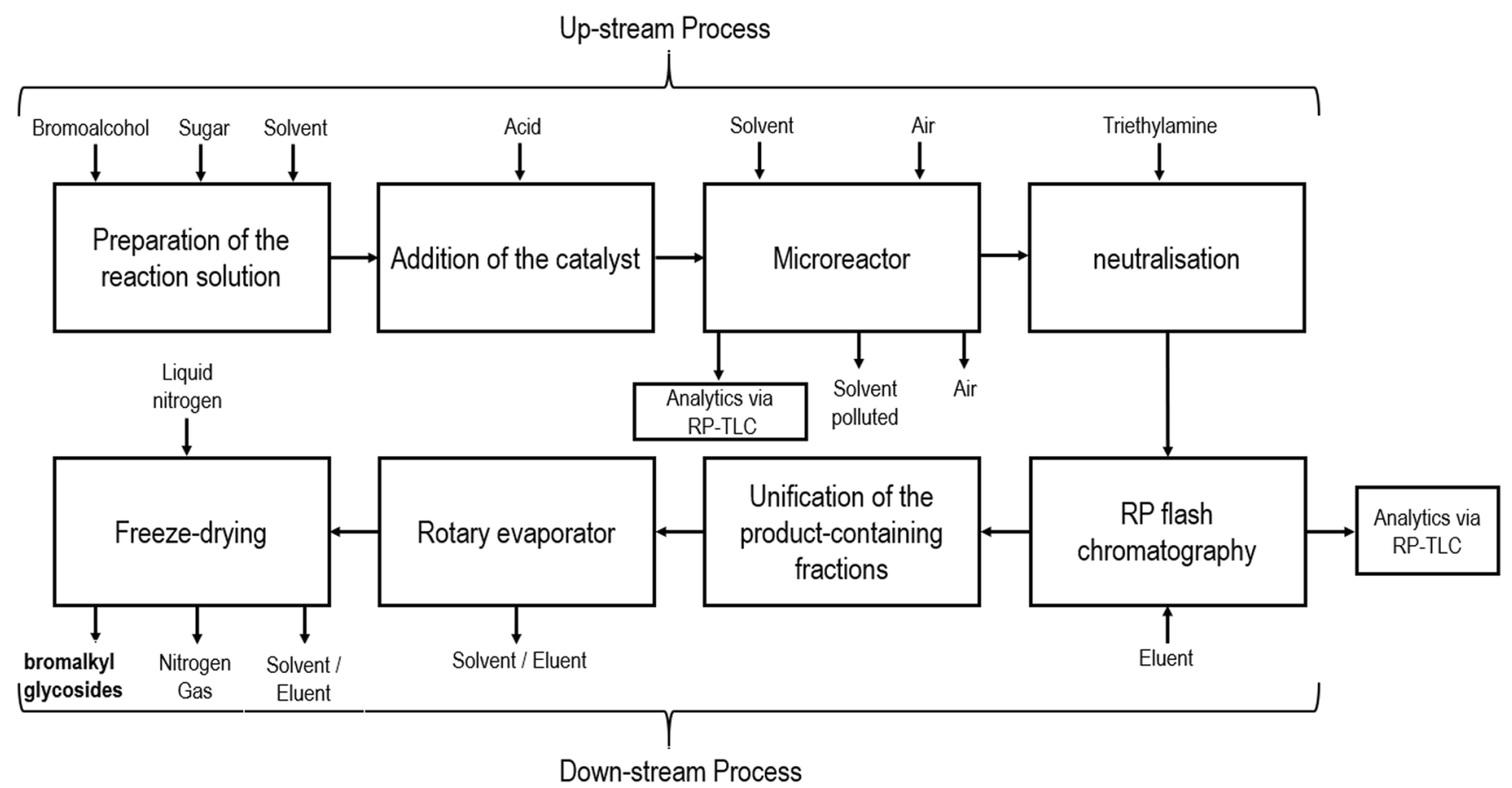

Fig. 2 Schematic of the overall process for obtaining the bromoalkyl glycosides from bromoalcohols and reducing sugars

glucose in the solution. In the experiments with 6-bromo1-hexanol, $6 \mathrm{~mL}$ DMSO was used and in the experiments with 8-bromo-1-octanol and 10-bromo-1-decanol $7 \mathrm{~mL}$.

Figure 3 shows the set-up of the microreactor. The reaction solution enters the reactor system through a syringe pump. Air enters the system when the syringe is changed. A three-way valve is used to remove air that arises during syringe changes before they enter the reactor system. From the three-way valve, the reaction solution enters the microreactor, which is located in an oil bath were the temperature can be adjusted. The effluent from the reactor is fractionated into $1.5 \mathrm{~mL}$ Falcons, which are located in a corresponding stand. The microreactor model LTF V from the manufacturer Little Things Factory $\mathrm{GmbH}$ was used. The microreactor is made of borosilicate and has a volume of $1.7 \mathrm{~mL}$. The channel size is $1 \mathrm{~mm}$. The total system has a volume of $3.1 \mathrm{~mL}$. The tubing and connections are made of Teflon, so that temperatures of up to $300{ }^{\circ} \mathrm{C}$ are possible without damaging components.

Column chromatography was performed with $60 \mathrm{~g} \mathrm{RP}$ silica gel. A mixture of ethanol and water served as eluent. In the experiments with 6-bromo-1-hexanol, a mixture of $30 \%$
Fig. 3 Set-up of the overall microreactor system

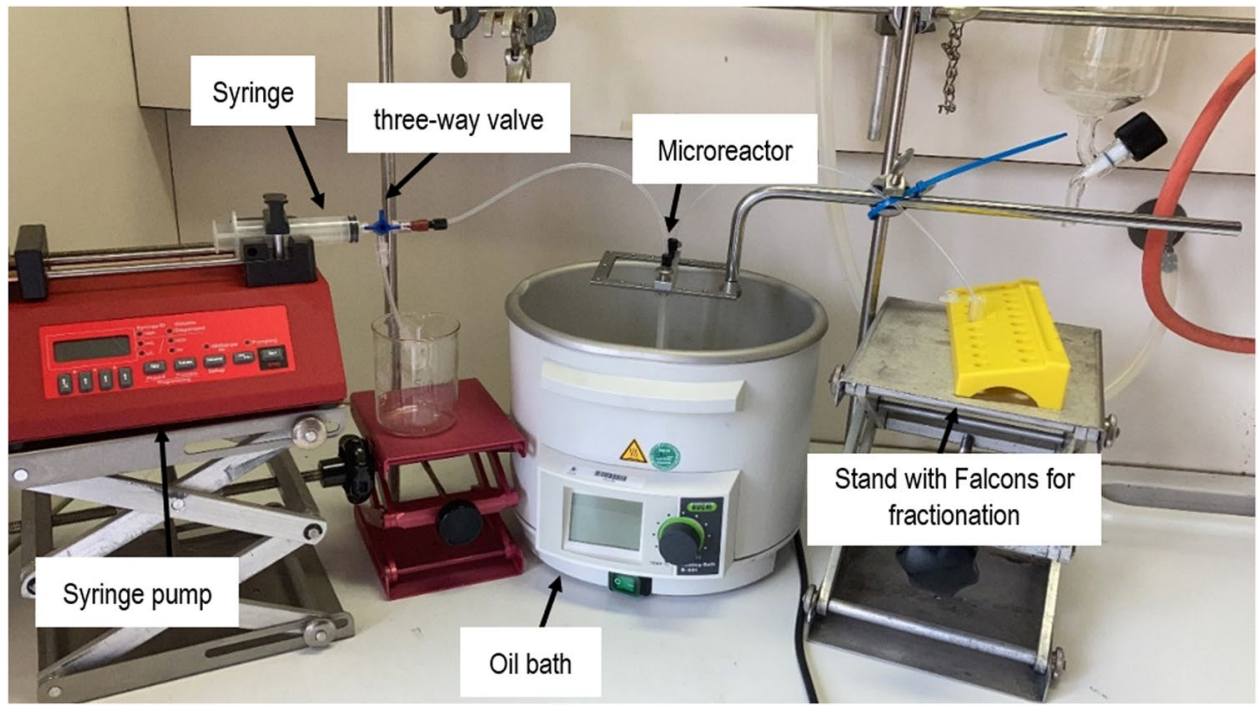


ethanol and $70 \%$ water was used, in the experiments with 8-bromo-1-octanola mixture of $30 \%$ ethanol and $70 \%$ water until DMSO was eluted. Subsequently, further purification was carried out with an eluent of $40 \%$ ethanol and $60 \%$ water. In the experiments with 10-bromo-1-decanol, a mixture of $40 \%$ ethanol and $60 \%$ water was used until the elution of the dibromide. Subsequently, further purification was carried out with an eluent of 50\% ethanol and 50\% water.

1H NMR and 13C NMR spectra were recorded on a Bruker Avance 200. Chemical shifts are reported in ppm relative to solvent signals $(\mathrm{CDCl} 3$ : $\delta \mathrm{H}=7.26 \mathrm{ppm}, \delta \mathrm{C}=77.0 \mathrm{ppm}$; DMSOd6: $\delta \mathrm{H}=2.49 \mathrm{ppm}, \delta \mathrm{C}=39.7 \mathrm{ppm} ; \mathrm{CD} 3 \mathrm{OD}: \delta \mathrm{H}=4.78 \mathrm{ppm}$, $\delta C=49.3 \mathrm{ppm})$. Signals were assigned by first-order analysis and assignments were supported, where feasible, by two-dimensional $1 \mathrm{H}, 1 \mathrm{H}$ and $1 \mathrm{H}, 13 \mathrm{C}$ correlation spectroscopy. Coupling constants are reported in $\mathrm{Hz}$.

Electrospray ionization mass spectra (ESI) were performed on Sciex API QTRAP Mass Spectrometer (AB Sciex LLC, Framingham, MA, United States). The mass spectrometer was operated in the positive ion mode with an electrospray voltage of $5000 \mathrm{~V}$ at $200{ }^{\circ} \mathrm{C}$, curtain gas at $25 \mathrm{psi}$, collision gas at 6 psi, nebulizing gas at 25 psi and auxiliary gas at 25 psi. All quadrupoles were working at unit resolution.

\section{6-Bromohexyl- $\alpha / \beta$-D-glucopyranoside $5(\alpha / \beta$ ratio 1.5:1) \\ ${ }^{1}$ H-NMR (200.1 MHz, CD 3 OD) $\boldsymbol{\alpha}$-compound: $\delta=4.81$} (d, $J=4.0,1 \mathrm{H}, \mathrm{H}-1), 4.00-3.33$ (m, 8H, H-2, H-3, H-4, H-5, H-6a, H-6b, $\mathrm{OCH}_{2}$ ), 3.49 (t, $J=6.6,2 \mathrm{H}, \mathrm{BrCH}_{2}$ ), 1.88 (quint, $J=6.7,2 \mathrm{H}, \mathrm{CH}_{2} \mathrm{CH}_{2} \mathrm{Br}$ ), $1.68\left(\mathrm{~m}, 2 \mathrm{H}, \mathrm{OCH}_{2} \mathrm{CH}_{2}\right.$ ), $1.49\left(\mathrm{~m}, 4 \mathrm{H}, 2 \times \mathrm{CH}_{2}\right)$;

ק-compound: $\delta=4.29(\mathrm{~d}, J=7.8,1 \mathrm{H}, \mathrm{H}-1), 4.00-3.33$ (m, 7H, H-3, H-4, H-5, H-6a, H-6b, $\mathrm{OCH}_{2}$ ), 3.49 (t, $J=6.6$, $\left.2 \mathrm{H}, \mathrm{BrCH}_{2}\right), 3.21(\mathrm{dd}, J=8.7,7.8,1 \mathrm{H}, \mathrm{H}-2), 1.88$ (quint, $J=6.7,2 \mathrm{H}, \mathrm{CH}_{2} \mathrm{CH}_{2} \mathrm{Br}$ ), $1.68\left(\mathrm{~m}, 2 \mathrm{H}, \mathrm{OCH}_{2} \mathrm{CH}_{2}\right), 1.49$ (m, $4 \mathrm{H}, 2 \times \mathrm{CH}_{2}$ );

${ }^{13} \mathbf{C}$-NMR $\left(50.3 \mathrm{MHz}, \mathrm{CD}_{3} \mathrm{OD}\right) \boldsymbol{\alpha}$-compound: $\delta=100.0$ (C-1), 77.8 (C-3), 75.1 (C-5), 73.6 (C-2), 71.8 (C-4), 68.9 $\left(\mathrm{OCH}_{2}\right), 62.7$ (C-6), $33.9\left(\underline{\mathrm{CH}}_{2} \mathrm{Br}\right), 30.4\left(\underline{\mathrm{CH}}_{2} \mathrm{CH}_{2} \mathrm{Br}\right), 29.0$ $\left(\mathrm{OCH}_{2} \mathrm{CH}_{2}\right), 26.4,26.2\left(2 \times \mathrm{CH}_{2}\right)$;

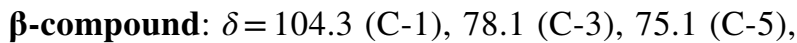
73.5 (C-2), $71.6(\mathrm{C}-4), 70.7\left(\mathrm{OCH}_{2}\right), 62.8$ (C-6), 34.4 $\left(\underline{\mathrm{C}}_{2} \mathrm{Br}\right), 30.5\left(\mathrm{CH}_{2} \mathrm{CH}_{2} \mathrm{Br}\right), 28.9\left(\mathrm{OCH}_{2} \underline{\mathrm{CH}}_{2}\right), 26.4,26.2$ $\left(2 \times \mathrm{CH}_{2}\right)$;

(ESI-MS): $\boldsymbol{m} / \boldsymbol{z}[\mathrm{M}+\mathrm{Na}]^{+}: 365.3$;

TLC (RP): $R_{\mathrm{f}}=0.51$ (mobile phase: ethanol/water $=1: 1.5$, colouring agent Cerium(IV) ammonium nitrate).

\section{8-Bromooctyl- $\alpha / \beta$-D- glucopyranoside $6(\alpha / \beta$ ratio 1.25:1) \\ ${ }^{1}$ H-NMR $\left(200.1 \mathrm{MHz}, \mathrm{CD}_{3} \mathrm{OD}\right) \boldsymbol{\alpha}$-compound: $\delta=4.79$ (d, $J=3.7,1 \mathrm{H}, \mathrm{H}-1), 3.99-3.29$ (m, 8H, H-2, H-3, H-4,}

H-5, H-6a, H-6b, $\mathrm{OCH}_{2}$ ), 3.46 (t, $J=6.7,2 \mathrm{H}, \mathrm{BrCH}_{2}$ ), 1.87 (quint, $\left.J=7.0,2 \mathrm{H}, \mathrm{C}_{2} \mathrm{CH}_{2} \mathrm{Br}\right), 1.66\left(\mathrm{~m}, 2 \mathrm{H}, \mathrm{OCH}_{2} \underline{\mathrm{H}}_{2}\right)$, 1.55-1.31 (m, $\left.4 \mathrm{H}, 4 \times \mathrm{CH}_{2}\right)$;

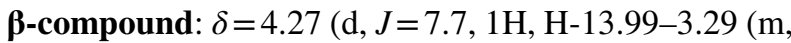
7H, H-3, H-4, H-5, H-6a, H-6b, $\mathrm{OCH}_{2}$ ), 3.46 (t, $J=6.7,2 \mathrm{H}$, $\mathrm{BrCH}_{2}$ ), 3.19 (dd, $J=8.9,7.7,1 \mathrm{H}, \mathrm{H}-2$ ), 1.87 (quint, $J=7.0$, $\left.2 \mathrm{H}, \underline{\mathrm{C}}_{2} \mathrm{CH}_{2} \mathrm{Br}\right), 1.66\left(\mathrm{~m}, 2 \mathrm{H}, \mathrm{OCH}_{2} \underline{\mathrm{C}}_{2}\right), 1.55-1.31(\mathrm{~m}$, $\left.4 \mathrm{H}, 4 \times \mathrm{CH}_{2}\right)$;

${ }^{13}$ C-NMR (50.3 MHz, $\left.\mathrm{CD}_{3} \mathrm{OD}\right) \boldsymbol{\alpha}$-compound: $\delta=100.1$ (C-1), 77.9 (C-3), 75.1 (C-5), 73.6 (C-2), 71.9 (C-4), 69.1 $\left(\mathrm{OCH}_{2}\right), 62.7$ (C-6), $34.0\left(\underline{\mathrm{CH}}_{2} \mathrm{Br}\right), 30.5\left(\mathrm{CH}_{2} \mathrm{CH}_{2} \mathrm{Br}\right), 30.3$ $\left(\mathrm{OCH}_{2} \mathrm{C}_{2}\right), 29.8,29.127 .2,27.0\left(4 \times \mathrm{CH}_{2}\right)$;

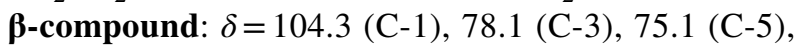
$73.6(\mathrm{C}-2), 71.7(\mathrm{C}-4), 70.8\left(\mathrm{OCH}_{2}\right), 62.8(\mathrm{C}-6), 34.4$ $\left(\mathrm{CH}_{2} \mathrm{Br}\right), 30.7\left(\mathrm{CH}_{2} \mathrm{CH}_{2} \mathrm{Br}\right), 30.5\left(\mathrm{OCH}_{2} \underline{\mathrm{CH}}_{2}\right), 29.8,29.1$ 27.2, $27.0\left(4 \times \mathrm{CH}_{2}\right)$;

(ESI-MS): $\boldsymbol{m} / \boldsymbol{z}[\mathrm{M}+\mathrm{Na}]^{+}: 393.3$;

TLC (RP): $R_{\mathrm{f}}=0.38$ (mobile phase: ethanol/water $=1: 1$, colouring agent Cerium(IV) ammonium nitrate).

\section{0-Bromodecyl- $\alpha / \beta$-D-glucopyranoside $7(\alpha / \beta$ ratio 2:1)}

spectroscopic data are consistent with published ones [18].

(ESI-MS): $\boldsymbol{m} / \boldsymbol{z}[\mathrm{M}+\mathrm{Na}]^{+}: 421.6$;

TLC (RP): $\mathrm{R}_{\mathrm{f}}=0.33$ (mobile phase: ethanol/water $=1: 1$, colouring agent Cerium(IV) ammonium nitrate).

Funding Open Access funding enabled and organized by Projekt DEAL.

\section{Declarations}

Ethical approval This article does not contain any studies with human participants or animals performed by any of the authors.

Informed consent Informed consent not applicable.

Conflicts of interest All authors certify that they have no affiliations with or involvement in any organization or entity with any financial interest or non-financial interest in the subject matter or materials discussed in this manuscript. All Author declare that they have no conflict of interest.

Open Access This article is licensed under a Creative Commons Attribution 4.0 International License, which permits use, sharing, adaptation, distribution and reproduction in any medium or format, as long as you give appropriate credit to the original author(s) and the source, provide a link to the Creative Commons licence, and indicate if changes were made. The images or other third party material in this article are included in the article's Creative Commons licence, unless indicated otherwise in a credit line to the material. If material is not included in the article's Creative Commons licence and your intended use is not permitted by statutory regulation or exceeds the permitted use, you will need to obtain permission directly from the copyright holder. To view a copy of this licence, visit http://creativecommons.org/licenses/by/4.0/. 


\section{References}

1. Nicotra F, Cipolla L, Peri F et al (2007) Chemoselective Neoglycosylation. In: Advances in Carbohydrate Chemistry and Biochemistry Volume 61, vol 61. Elsevier, pp 353-398

2. Gabius H-J, Siebert H-C, André S et al (2004) Chemical biology of the sugar code. ChemBioChem 5:740-764. https://doi.org/10. 1002/cbic. 200300753

3. Davis BG (2000) Hand in glove: Investigating Glycocode. Chemistry \& Industry: 134-138

4. Kren V, Martínková L (2001) Glycosides in medicine: "The role of glycosidic residue in biological activity." Curr Med Chem 8:1303-1328. https://doi.org/10.2174/0929867013372193

5. Hwu JR, Hsu C-I, Hsu M-H et al (2011) Glycosylated nordihydroguaiaretic acids as anti-cancer agents. Bioorg Med Chem Lett 21:380-382. https://doi.org/10.1016/j.bmcl.2010.10.137

6. Dubber M, Lindhorst TK (2000) Synthesis of carbohydrate-centered oligosaccharide mimetics equipped with a functionalized tether. $\mathbf{J}$ Org Chem 65:5275-5281. https://doi.org/10.1021/jo000432s

7. Lassaletta JM, Schmidt RR (1996) Glycosyl Imidates, 75. Synthesis of the Hexasaccharide Moiety of Globo H (Human Breast Cancer) Antigen. Liebigs Ann Recl 1996:1417-1423. https://doi. org/10.1002/jlac.199619960913

8. Schmidt RR (1986) New methods for the synthesis of glycosides and oligosaccharides?Are there alternatives to the Koenigs-Knorr Method? [New Synthetic Methods (56)]. Angew Chem Int Ed Engl 25:212-235. https://doi.org/10.1002/anie.198602121

9. Schmidt RR, Michel J (1980) Facile synthesis of $\alpha-$ and $\beta-O-$ Glycosyl Imidates; preparation of glycosides and disaccharides. Angew Chem Int Ed Engl 19:731-732. https://doi.org/10.1002/ anie. 198007311

10. Hayes MR, Pietruszka J (2017) Synthesis of Glycosides by Glycosynthases. Molecules 22. https://doi.org/10.3390/molecules2 2091434

11. Fischer E (1893) Ueber die Glucoside der Alkohole. Ber Dtsch Chem Ges 26:2400-2412. https://doi.org/10.1002/cber.18930 260327

12. Bornaghi LF, Poulsen S-A (2005) Microwave-accelerated Fischer glycosylation. Tetrahedron Lett 46:3485-3488. https://doi.org/10. 1016/j.tetlet.2005.03.126
13. Guchhait G, Misra AK (2011) Efficient glycosylation of unprotected sugars using sulfamic acid: a mild eco-friendly catalyst. Catal Commun 14:52-57. https://doi.org/10.1016/j.catcom.2011.07.016

14. Polanki IK, Kurma SH, Bhattacharya AK (2015) Direct glycosylation of unprotected and unactivated sugars using Bismuth Nitrate Pentahydrate. J Carbohydr Chem 34:196-205. https://doi.org/10. 1080/07328303.2015.1028585

15. Roy B, Mukhopadhyay B (2007) Sulfuric acid immobilized on silica: an excellent catalyst for Fischer type glycosylation. Tetrahedron Lett 48:3783-3787. https://doi.org/10.1016/j.tetlet.2007.03.165

16. Augé J, Sizun G (2009) Ionic liquid promoted atom economic glycosylation under Lewis acid catalysis. Green Chem 11:1179. https://doi.org/10.1039/b904692e

17. Park T-J, Weïwer M, Yuan X et al (2007) Glycosylation in room temperature ionic liquid using unprotected and unactivated donors. Carbohydr Res 342:614-620. https://doi.org/10.1016/j. carres.2006.11.022

18. Williams L, Schunck N, Götz KH et al (2019) Systematic synthesis and characterization of a series of different bromoalkylglycosides by Fischer glycosylation. Carbohydr Res 486:107841. https://doi.org/10.1016/j.carres.2019.107841

19. Denčić I, Noël T, Meuldijk J et al (2013) Micro reaction technology for valorization of biomolecules using enzymes and metal catalysts. Eng Life Sci 13:326-343. https://doi.org/10.1002/elsc. 201200149

20. Kockmann N (2008) Transport phenomena in micro process engineering: With 17 tables. Heat and mass transfer. Springer, Berlin

21. Lindhorst TK (2007) Essential of carbohydrate chemistry and biochemistry: With 150 new exercises, 3., completely rev. and enl. ed. Wiley-VCH, Weinheim

22. Emig G, Klemm E (2005) Technische Chemie: Einführung in die Chemische Reaktionstechnik ; mit 47 Tabellen, 5, aktualisierte und erg. Aufl. Springer-Lehrbuch. Springer, Berlin, Heidelberg

23. Aronow J, Stanetty C, Baxendale IR et al (2019) Methyl glycosides via Fischer glycosylation: translation from batch microwave to continuous flow processing. Monatsh Chem 150:11-19. https:// doi.org/10.1007/s00706-018-2306-8

Publisher's note Springer Nature remains neutral with regard to jurisdictional claims in published maps and institutional affiliations. 